\title{
Kolekcja książek Męcińskich i Zborowskich w zbiorach Miejskiej Biblioteki Publicznej im. Juliusza Słowackiego w Tarnowie*
}

Miejska Bibliotek Publiczna im. Juliusza Słowackiego w Tarnowie posiada w swoich zbiorach kolekcje książek i innych materiałów bibliotecznych (muzykaliów, variów, kartografii) należących przed 1945 r. do znanych w regionie rodów ziemiańskich: Cieleckich, Konopków, Stadnickich, Żabów, Sanguszków i innych ${ }^{1}$ czy też rodów znanych w Lubelskiem: Iżyckich i Zbyszewskich. Jedna $\mathrm{z}$ tego typu kolekcji należała najpierw do Męcińskich, a następnie - Zborowskich. Badania bibliologiczne i krytyka dostępnych źródeł pozwoliły poznać losy księgozbioru z Partynia.

\section{Historia właścicieli Partynia: Męcińskich i Zborowskich}

Małopolski ród Męcińskich herbu Poraj wywodził się z Kurozwęk. Reprezentowany był przez dwie gałęzie: żarecką, której przedstawiciele mogli tytułować się hrabiami², i działoszyńska, z której wywodził się

* Artykuł stanowi skróconą wersją pracy magisterskiej napisanej pod kierunkiem dr Ewy Wójcik i obronionej w lipcu 2013 r. w Instytucie Informacji Naukowej i Bibliotekoznawstwa Uniwersytetu Pedagogicznego im. KEN w Krakowie, pt. Księgozbiór dawnych właścicieli Partynia Męcińskich $i$ Zborowskich $w$ zbiorach Miejskiej Biblioteki Publicznej im. Juliusza Słowackiego w Tarnowie. Praca jest dostępna w bibliotece instytutu oraz w Dziale Starych Druków i Książki XIX-wiecznej w MBP w Tarnowie.

1 Zob. Miejska Biblioteka Publiczna im. Juliusza Słowackiego w Tarnowie, Ksiażka XIX-wieczna, w: Zbiory i Kolekcje [http://www.biblioteka.tarnow.pl/zbiory] (20.01.2014).

${ }^{2}$ Zob. J.S. Dunin-Borkowski, Genealogie żyjacych utytułowanych rodów polskich, Lwów 1895, s. 386. 
Józef Gabriel Męciński (1839-1921), właściciel dóbr partyńskich koło Tarnowa ${ }^{3}$.

Protoplastą linii, z której wywodził się kolejny właściciel Partynia - Jan Marcin Zborowski herbu Jastrzębiec (1862-1914) - był Maksymilian Zborowski, który 1 IX 1792 r. otrzymał od cesarza Leopolda II Habsburga tytuł hrabiego ${ }^{4}$. Wnuk Maksymiliana - Prosper Maksymilian (1807-1872), kompozytor, miał liczne potomstwo, w tym trzech synów, z których Jan Marcin był mężem jednej z córek J.G. Męcińskiego ${ }^{5}$.

J.G. Męciński był synem Stanisława Męcińskiego (1816-1866) z Kurozwęk oraz Ludwiki z domu Polikowskiej (1821-1900), dziedziców Łowczy i Malinówki w powiecie chełmskim 6 . W 1863 roku, kiedy wybuchło powstanie styczniowe, 24-letni Józef Gabriel walczył pod rozkazami Mariana Langiewicza, a następnie był adiutantem płk. Dionizego Czachowskiego. W bitwie pod Kępą (6 IX 1863 r.) jako rotmistrz biorący udział w obronie Czachowskiego stracił rękę oraz odniósł liczne rany, m.in. głowy ${ }^{7}$.

Po powstaniu styczniowym władze carskie skonfiskowały majątek rodziców Męcińskiego w Łowczy, a on sam, uzyskawszy warunkową amnestię, wyjechał wraz z matką L. Męcińską do Galicji i osiadł w należącym do Dobrzyńskich Partyniu, niedaleko Tarnowa ${ }^{8}$. 14 XI 1865 r. poślubił Helenę Marię Annę Dobrzyńską (1845-1906)9 , córkę Antonie-

${ }^{3}$ Józef G. Męciński - podobnie jak jego dziadek, Jan Nepomucen Męciński - niesłusznie tytułował się hrabią. Linia działoszyńska, z której pochodził, nie posiadała praw do używania tytułu hrabiowskiego. Jednak linia żarowiecka w Małopolsce w $1801 \mathrm{r}$. otrzymała od władz austriackich potwierdzenie tytułu hrabiowskiego - począwszy od Adama Wojciecha Męcińskiego. W Małopolsce przedstawicielami tej linii byli właściciele majątku w Dukli na Podkarpaciu. Błąd w nazywaniu J. Męcińskiego hrabia nie dziwi, ponieważ już mu współcześni tak go tytułowali. Również napisy na nagrobkach w kaplicy rodzinnej w Łęgu wskazuja, że Męciński używał tytułu hrabiowskiego.

${ }^{4}$ Zob. tamże, s. 670.

${ }^{5}$ Zob. Wiadomości bieżace o rzeczach polskich, ,Tygodnik Wielkopolski”, 13:1872, s. 18.

${ }^{6}$ Data śmierci według klepsydry (w publikacjach znajdujemy błędną informację). Ludwika Męcińska w chwili śmierci miała 79 lat. Została pochowana w Łęgu, w rodzinnej kaplicy wybudowanej przez jej syna J.G. Męcińskiego - zob. Kronika miejscowa i zamiejscowa, „Pogoń”, 8:1900, s. 3.

7 Zob. W.J. Paszkowski, Pułkownik Dionizy Czachowski: bohater powstania 1863 roku, Radom [1937], s. 43.

8 Zob. A. Kunisz, Udziat ziemi tarnowskiej w powstaniu styczniowym, Kraków 1990, s. 173. Autor publikacji wymienia właścicieli Partynia - Dobrzyńskich - wśród osób włączających się w powstanie styczniowe.

${ }^{9}$ Błędną datę urodzin Heleny Marii podaje Antoni Długoń w publikacji Dawni właściciele Partynia. Opowiadania starego stugi Stanisława (Tuchów 2003) oraz Marek J. Minakowski w haśle Helena Maria Anna Dobrzyńska h. Jelita [http://www.sejm-wielki.pl/b/lu.16310] (21.01.2014). 
go Aleksandra Dobrzyńskiego herbu Jelita ${ }^{10}$, posła na Sejm Krajowy w 1866 roku, i Wiktorii Świderskiej (1809-1885).

J.G. Męciński w czasie swojego długiego życia piastował wiele funkcji społecznych, m.in. od 1873 do 1914 r. był obdarzony mandatem poselskim. Stenogramy swych wystapień sejmowych opublikował pt. Poset J.M. swoim wyborcom (Kraków 1883) ${ }^{11}$. Od $26 \mathrm{~V} 1897$ r. do I wojny światowej sprawował funkcję prezesa Towarzystwa Wzajemnych Ubezpieczeń „Florianka" w Krakowie ${ }^{12}$. W ramach działalności Krakowskiego Towarzystwa Rolniczego wziął w 1873 r. udział w Wystawie Powszechnej w Wiedniu ${ }^{13}$. Wraz z żoną angażował się w akcje charytatywne - m.in. wspierał finansowo budowę pomnika Adama Mickiewicza w Tarnowie ${ }^{14}$ oraz wydanie Słownika geograficznego Królestwa Polskiego ${ }^{15}$. W 1884 r. założył na terenie powiatu dąbrowskiego Komitet Ratunkowy, na czele którego też staną; zastępcą przewodniczącego został baron Jan Konopka z Brnia ${ }^{16}$.

Józef Gabriel miał również powiązania ze środowiskiem literackim jako czytelnik i sponsor. W 1885 r. wziął udział w bankiecie na cześć Władysława Żeleńskiego ${ }^{17}$. W ramach zbierania datków na fundusz Kraszewskiego apelował: „Język poniewierany, wyparty ze szkoły, sądu i urzędu, tylko w literaturze i na scenie odzywać się jeszcze może. A więc za wspólną naszą pomoca, panowie, niech słyszą go Niemcy, co prędzej ze sceny teatru polskiego w Poznaniu. Niech brzmi im w uszach!"18.

Pełne uhonorowanie zasług powstańczych J.G. Męcińskiego nastapiło dopiero w II Rzeczypospolitej. Po przeprowadzonym postępowaniu

${ }^{10}$ Antoni Aleksander Dobrzyński żył w latach 1790-1872. A. Długoń niesłusznie tytułuje Dobrzyńskich hrabiami. W Małopolsce faktycznie istniała inna linia Dobrzyńskich (wywodząca się od Faustyna Dobrzyńskiego), posiadająca austriacki tytuł hrabiowski od XVIII w. - zob. Genealogia Polska, Dobrzyński h. Jelita [http://polishgenealogy.blogspot.com/2009/08/dobrzynski.html] (21.01.2014 r.).

${ }^{11}$ Zob. B. Jaśkiewicz, J. Zdrada, Męciński Józef Gabriel, w: PSB, t. 20, s. 496.

12 Jako przedstawiciel towarzystwa brał udział w pogrzebie Jana Dzierżysława Tarnowskiego z Dzikowa w Krakowie w 1894 r. - zob. J.D. Tarnowski, Jan Tarnowski z Dzikowa, Kraków 1898, s. 178.

${ }^{13}$ Zob. H.E. Gintl, Wykaz udzialu Galicji i Wielkiego Księstwa Krakowskiego na Powszechnej Wystawie 1873 w Wiedniu, Wiedeń 1873, s. 43.

${ }^{14}$ Zob. M. Czosnyka, Partyń - pałac w Łęgu Tarnowskim: historia i współczesność. Publiczne Gimnazjum im. Rodzin Męicińskich i Zborowskich, Łęg Tarnowski 2011, s. 64.

${ }^{15}$ Zob. Lista osób, które dopomagaja nam stale w pracy [...], [w:] Słownik geograficzny Królestwa Polskiego i innych krajów stowiańskich, t. 2, Warszawa 1881, s. XI (Dodatek).

${ }^{16}$ Zob. Komitet ratunkowy Dabrowski, „Pogoń”, 14:1884, s. 3.

${ }^{17}$ Zob. Bankiet na cześć Żeleńskiego, „Gazeta Toruńska”, 52:1885, s. 4.

${ }^{18}$ P. Czartoryski-Sziler, Józef Ignacy Kraszewski - ojciec polskiej powieści historycznej. Jubileusz 50-lecia pracy twórczej [http://archiwum.dlapolski.pl/kultura/readarticle.php?article_id=275] (13.12.2013). 
kwalifikacyjnym jego nazwisko zostało wpisane w 1920 r. do Imiennego wykazu weteranów powstań narodowych 1831, 1848 i $1863^{19}$, a on sam otrzymał potwierdzenie posiadanego stopnia oficerskiego. Pośmiertnie J.G. Męcińskiego uhonorowano Krzyżem Srebrnym Orderu Virtuti Militari V klasy ${ }^{20}$. Józef Gabriel zmarł 19 IV 1921 r. w Andrychowie, gdzie spędził ostatnie lata życia u córki Róży Bobrowskiej. Pochowany został obok żony, w kaplicy rodowej w Łęgu.

Helena Wiktoria Zborowska (1876-1943) urodziła się w Partyniu jako starsza z córek Józefa Gabriela i Heleny Marii Męcińskich. W wieku 20 lat (17 X 1896 r.) poślubiła starszego od niej o 14 lat Jana Marcina Zborowskiego, właściciela Zgłobic, z którym miała troje dzieci: Andrzeja Zbigniewa (1899-1919) ${ }^{21}$, Aleksandra (1901-1979) oraz Irenę (19021929) ${ }^{22}$. Po śmierci męża oraz starszego syna hrabina przekazała Partyń młodszemu potomkowi Aleksandrowi, a sama z córką Ireną w $1925 \mathrm{r}$. przeprowadziła się do dworku w Pogwizdowie (wchodzącym w skład posiadłości Heleny Wiktorii). Mieszkała w nim wraz z córką aż do jej niespodziewanej śmierci w 1929 roku.

H.W. Zborowska była powieściopisarką, autorką nowel i esejów. Publikowała najczęściej pod pseudonimem Blanka Halicka ${ }^{23}$ lub posługiwała się inicjałami od niego, ewentualnie skrótem $\mathrm{Bha}^{24}$. Prawdopodobnie thumaczyła także na polski powieści francuskie ${ }^{25}$. Jej debiut literacki przypadł na 1901 rok, kiedy we Lwowie ukazała się jej powieść Kto zwycięży. Kolejne teksty, których tematyka oscylowała wokół patriotyzmu, przyjaźni, miłości oraz emancypacji kobiet, powstawały w Partyniu, a potem - w Pogwizdowie ${ }^{26}$. Od 1901 r. wybrane utwory publikowała także w od-

${ }^{19}$ Zob. M. Czosnyka, Partyń - pałac w Łęgu Tarnowskim..., s. 62.

${ }^{20}$ Zob. jak wyżej.

${ }^{21}$ Andrzej Zbigniew był porucznikiem pułku szwoleżerów Wojska Polskiego. Odznaczony Krzyżem Niepodległości, zmarł tragicznie podczas pełnienia służby wojskowej.

${ }^{22}$ Irena, urodzona w Zgłobicach, była malarka. W 1928 r. poślubiła porucznika 20 Pułku Ułanów Stanisława Drzewińskiego (ur. 1901 r.). Zmarła w sanatorium w Arco we Włoszech.

${ }^{23}$ Zob. L. Czarkowski, Pseudonimy i kryptonimy Polskie, Wilno 1922, s. 113.

${ }^{24}$ Zob. Stownik pseudonimów pisarzy polskich XV - 1970, t. 4, pod red. E. Jankowskiego, Wrocław 1996, s. 799.

${ }^{25}$ Zob. M. Czosnyka, Blanka Halicka właściwie Helena Zborowska - zapomniana powieściopisarka historyczna regionu tarnowskiego, „Rocznik Tarnowski”, 15:2010, s. 144.

${ }^{26} \mathrm{~W}$ sumie hrabina wydała 17 utworów, niektóre z nich były wznawiane. Najbardziej znane to: Krwawe lata (1812-1814). Powieść, Lwów 1903; Nowele włoskie, Lwów 1903; Nemezis. Powieść, Kraków 1907; Btędni rycerze. Powieść z dziejów emigracji, t. I-II, Kraków 1912 oraz Dzień Zmartwychwstania. Siwa pani. Dwie historie prawdziwe, Kraków 1922. 
cinkach w „Dzienniku Polskim”27. Helena Wiktoria Zborowska parała się również krytyką literacką.

H.W. Zborowska podobnie jak jej matka włączała się w tarnowskie inicjatywy charytatywne ${ }^{28}, \mathrm{np}$. w 1912 r. zajmowała się zbiórką funduszy na budowę kościoła i szkoły polskiej w Adampolu ${ }^{29}$. Była też członkiem zwyczajnym Towarzystwa Tatrzańskiego ${ }^{30}$. Pisarka zmarła 10 V 1943 r. w Pogwizdowie i została pochowana obok męża w kaplicy rodzinnej w Łęgu.

Jan Marcin (1836-1899), syn P.M. Zborowskiego i Barbary z Bobrowskich, urodził się w Bieździedzi. W młodości był rotmistrzem 2 Pułku Ułanów Księcia Karola Filipa Schwarzenberga ${ }^{31}$ i miał tytuł szambelana dworu Jego Cesarskiej Mości Franciszka Józefa. Mianowany porucznikiem w 1897 roku, następnie w 1901 r. jako rotmistrz I klasy w 2 Pułku Ułanów Austriackich został przeniesiony w stan spoczynku ${ }^{32}$. Od 1900 r. Jan Marcin był członkiem Rady Powiatowej Tarnowskiej, a w sierpniu 1914 r. wszedł w skład Powiatowego Komitetu Narodowego w Tarnowie $^{33}$. J.M. Zborowski popełnił samobójstwo i został pochowany w kaplicy rodowej w Łęgu.

Aleksander Zborowski, młodszy syn Heleny i Jana Zborowskich, urodził się w Zgłobicach. Był ostatnim dziedzicem majątku w Partyniu, drugiej - po dobrach Sanguszków - co do wielkości posiadłości w ziemi tarnowskiej. W czasie I wojny światowej, w listopadzie 1918 roku, A. Zborowski, wówczas uczeń gimnazjum we Lwowie, brał udział w obronie tego miasta ${ }^{34}$. Po zakończeniu działań wojennych podjął studia rolnicze na tzw. kursach Turnaua we Lwowie, które miały przygotować ziemianina do dobrego zarządzania ojcowizną ${ }^{35}$. 30 IV 1924 r. Aleksander poślubił Marię Ziemińską (1903-1971), córkę Józefa Ziemińskiego i Zofii Broni-

${ }^{27}$ Zob. np.: Rozbitki, „Dziennik Polski”, 34:1901, nr 92-166, s. 1; Miłość Tytana, „Dziennik Polski”, 38:1905, nr 3-26, s. 1.

${ }^{28}$ Zob. Kronika miejscowa i zamiejscowa, „Pogoń”, 8:1896, s. 4.

${ }^{29}$ Zob. Polacy w Turcyi, „Ilustrowany Kurier Codzienny”, 281:1912, s. 5.

${ }^{30}$ Zob. Pamiętnik Towarzystwa Tatrzańskiego za lata 1919-1920, Kraków 1920, s. 72

${ }^{31}$ Zob. Kronika miejscowa i zamiejscowa, „Pogoń”, 45:1896, s. 5.

${ }^{32}$ Zob. Kronika miejscowa i zamiejscowa, „Pogoń”, 8:1901, s. 2.

${ }^{33}$ Obok niego w komitecie zasiadali m.in. Tadeusz Tertil - prezydent miasta Tarnowa, Wincenty Witos, Stefan Język - ówczesny kierownik biblioteki Towarzystwa Szkoły Ludowej w Tarnowie.

${ }^{34}$ Zob. A. Długoń, dz. cyt., s. 35.

35 A. Zborowski wykazywał zainteresowania artystyczne, w szczególności muzyką i sztukami pięknymi. Świadectwem przejawianych zdolności jest wybudowany według jego projektu w Pogwizdowie drewniany dwór, w którym zamieszkała jego matka H. Zborowska - zob. jak wyżej. 
kowskiej herbu Osęk, właścicieli majątku Łukowa. Maria i Aleksander mieli czworo dzieci: Zbigniewa Mariana (1925-1970), Henryka (1926-), Jana (1927-2006) oraz Andrzeja (1935- ). Wszyscy czterej przyszli na świat w Partyniu, gdzie spędzili dzieciństwo. W 1945 r. władze PRL pozbawiły A. Zborowskiego majątku ziemskiego i zakazały przebywania na terenie powiatu tarnowskiego.

\section{Biblioteki w pałacyku partyńskim i dworze pogwizdowskim po 1945 roku}

Pałacyk w Partyniu koło Tarnowa to jeden z niewielu na tym terenie przykładów siedziby w stylu neorenesansowym. Jest to budowla murowana, piętrowa, założona na planie zbliżonym do kwadratu z przylegającą od wschodu kwadratowa, czterokondygnacyjną wieżą zwieńczoną strzelistym hełmem, pokrytym dwubarwną dachówką. W czasach PRL pierwotny układ wnętrz został zniszczony, a część wyposażenia - wraz z omawianym

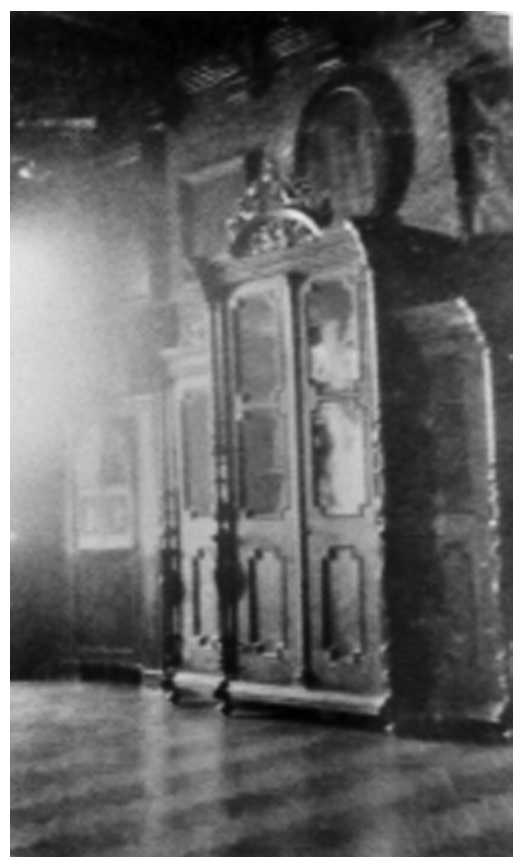

Fot. 1. Szafa biblioteczna w Partyniu. Źródło: archiwum rodzinne H. Zborowskiego księgozbiorem oraz 42 obrazami (m.in. portretem rodziny Stefana Zborowskiego, brata J. Zborowskiego, pędzla Jacka Malczewskiego) - w 1945 r. przejęło Muzeum Ziemi Tarnowskiej ${ }^{36}$. Obecnie w pałacyku działa Publiczne Gimnazjum im. Rodzin Męcińskich i Zborowskich w Łęgu Tarnowskim.

Biblioteka rodzinna znajdowała się na parterze pałacyku, po prawej stronie holu. O jej urządzeniu można mówić jedynie $\mathrm{w}$ oparciu o zachowane zdjęcia z lat dwudziestych XX wieku. Wyposażenie biblioteki stanowiły przeszklone dębowe szafy biblioteczne, komoda oraz kanapa $\mathrm{z}$ dwoma fotelami obitymi pluszem. Wystroju dopełniały ściany pokryte ozdobną tapetą z wzorem roślinnym, obrazy $\mathrm{w}$ drewnianych grubych ramach oraz żyrandol. Księgozbiór zapewne nigdy nie posiadał katalogu. Według spisu mienia zabezpieczo-

${ }^{36}$ Archiwum Państwowe w Krakowie Oddział w Tarnowie (dalej APwKOT), MOT $33 / 273 / 34$, Sprawozdanie z prac wykonanych przy zabezpieczaniu zbiorów bibliotecznych na terenie pow. tarnowskiego i dębickiego od dn. I.II.1945 r. 
nego i przejętego przez skarb państwa w 1945 r. w Partyniu znajdowało się prawdopodobnie od 814 do 1116 woluminów oraz archiwum rodzinne ${ }^{37}$.

Ilościowo nie była to imponująca kolekcja, jednak należy pamiętać także o zbiorze znajdującym się w modrzewiowym dworze-samotni pisarki H.W. Zborowskiej w Pogwizdowie. Według dokumentów z 1945 r. przechowywano tam - w dwóch szafach dębowych z oszklonymi drzwiczkami i dwiema szufladami - 1071 woluminów książek polskich i obcych ${ }^{38}$. Ponadto książki w bibliotece w Pogwizdowie zajmowały także komodę, dwie półki ścienne oraz etażerkę. A. Długoń wspomina w swojej publikacji też o tzw. biblioteczce obrotowej, która równocześnie służyła jako niewielki stoliczek - jednakże w dokumentacji z zabezpieczenia mienia podworskiego mebel ten nie został wymieniony ${ }^{39}$.

Dla kolekcji z Pogwizdowa istniał niedatowany spis, wykonany własnoręcznie przez H.W. Zborowską na 21 kartach formatu A4, prawdopodobnie $\mathrm{w}$ celu orientacji w układzie księgozbioru, ponieważ książki zostały wpisane na listę według rozmieszczenia ${ }^{40}$. W wykazie odnotowano: autora, tytuł (najczęściej skrócony), liczbę woluminów, wyjątkowo rok wydania oraz liczbę tomów ${ }^{41}$. Na liście można również znaleźć przy niektórych pozycjach zapisane czerwonym lub szarym ołówkiem imiona osób, które prawdopodobnie pożyczały książki od pisarki.

Według spisu w księgozbiorze było osiem starych druków. W kolekcji przeważała beletrystyka (624 pozycji), która stanowiła $51 \%$ całości, z wyraźna przewagą tytułów w języku polskim. Dodatkowo H.W. Zborowska gromadziła pozycje z zakresu literaturoznawstwa (4\% księgozbioru). Drugi co do wielkości dział to książki historyczne (ok. 24\%), wśród nich dotyczące też genealogii i heraldyki. Obok tego typu publikacji pojawiają się książki z historii sztuki, nauk polityczno-społecznych, religii, geografii i turystyki. Nie zabrakło też wydawnictw encyklopedycznych, słowników, podręczników szkolnych.

${ }^{37}$ APwKOT, MOT 33/273/34, Spis zabezpieczonych przedmiotów sztuki w Partyniu w dniu 7 lutego 1945 r.; MOT 33/273/34, Do Starostwa Powiatowego w Tarnowie.

${ }^{38}$ APwKOT, MOT 33/273/34, Spis książek i przedmiotów sztuki zabezpieczonych z dnia 14 lutego w Pogwizdowie (Odpis).

${ }^{39}$ Zob. A. Długoń, dz. cyt., s. 27.

${ }^{40}$ APwKOT, Archiwum rodziny Zborowskich z Partynia 33/227/3, Odręczny spis książek.

${ }^{41}$ Zapisywanie przez H.W. Zborowską przy niektórych tytułach dat wydania może sugerować, że w Partyniu pozostały inne wydania danej pozycji, a data została odnotowana dla odróżnienia egzemplarzy i uszczegółowienia listy. Badania proweniencyjne nad zachowanym fragmentem księgozbioru z Partynia i Pogwizdowa w MBP w Tarnowie wykazały dwa wydania m.in. Pana Tadeusza Adama Mickiewicza oraz Ogniem i mieczem Henryka Sienkiewicza. Jednakże informacja ta nie może być jednoznacznym dowodem na istnienie w Partyniu innych wydań poszczególnych tytułów. 


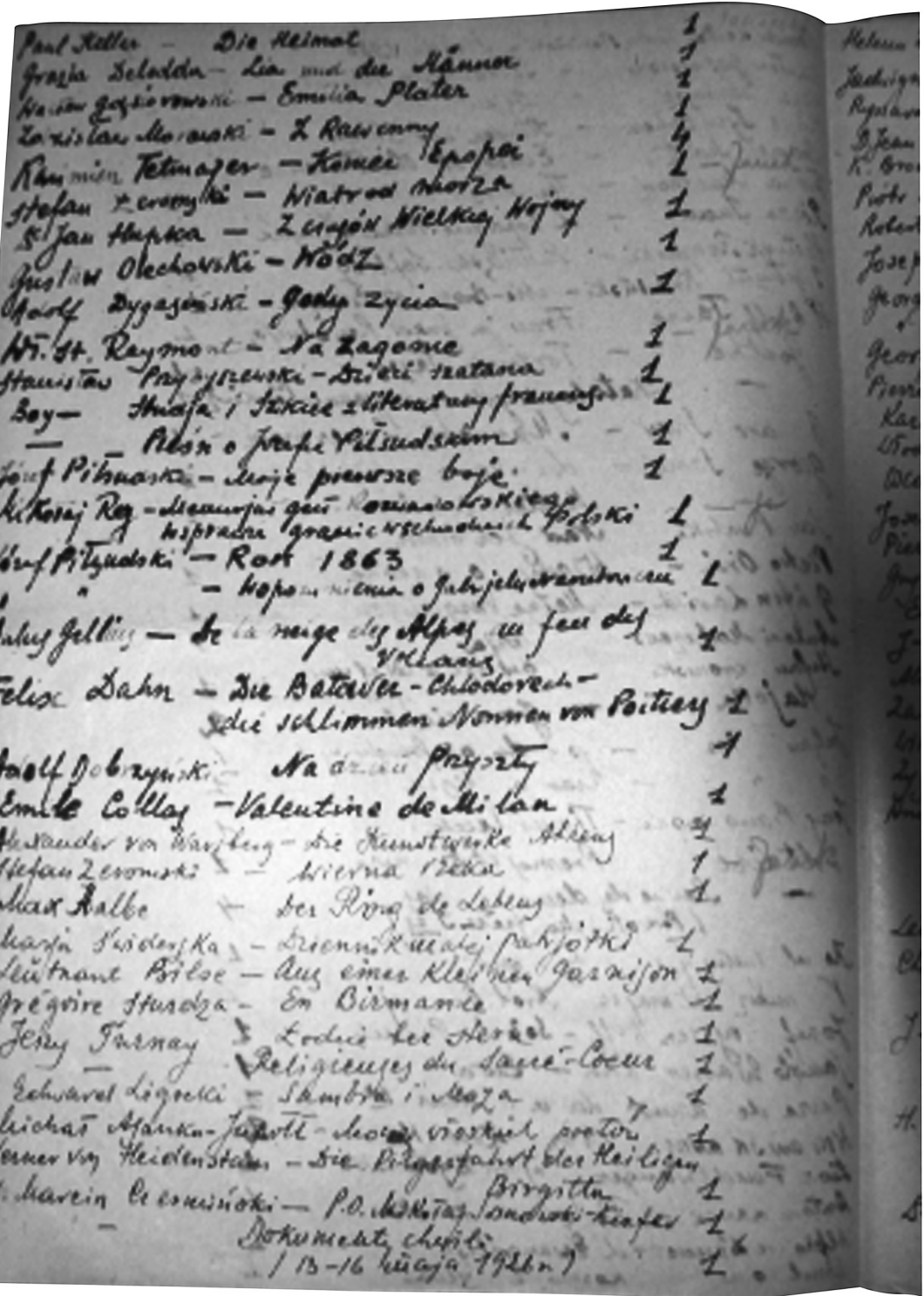

Fot. 2. Jedna ze stron wykazu książek H.W. Zborowskiej. Źródło: APwKOT, Archiwum rodziny Zborowskich z Partynia 33/227/3, Odręczny spis książek (zdjęcie: M. Sobol) 
H.W. Zborowska zgromadziła 14 periodyków (roczników lub pojedynczych numerów) m.in. „Izys Polska”, „Przegląd Polski”, „Przegląd Powszechny”, „Wanda. Tygodnik Polski Płci Pięknej i Literaturze Poświęcony". Z czasopism obcojęzycznych w Pogwizdowie znalazły się tytuły niemieckie i francuskie, np. „Geist der Zeit: Ein Journal für Geschichte, Politik, Geographie, Staaten- und Kriegskunde und Literatur”, „Revue des Deux Mondes".

Księgozbiór z Pogwizdowa pod względem językowym cechował się zdecydowaną przewagą wydawnictw w języku polskim (aż 70\%). Wśród publikacji w językach obcych przeważały książki w języku francuskim $(16 \%)$, w mniejszym stopniu gromadzono tytuły w języku niemieckim (9\%) i angielskim (4\%). 1\% stanowiły pojedyncze wydawnictwa w językach: czeskim, włoskim i duńskim.

Z zachowanych rachunków i pokwitowań księgarskich wiadomo o zakupach H.W. Zborowskiej u Władysława L. Anczyca i Spółki na kwotę 431,40 koron. Natomiast J.M. Zborowski u tarnowskiego księgarza Zygmunta Jelenia wydał 295 koron na Gramatykę tacińska II Zygmunta Samolewicza ${ }^{42}$. Wiadomo też o zakupach książek dokonanych przez innych członków rodziny w księgarni Hermana Altenberga we Lwowie ${ }^{43}$.

Faktyczna wielkość przejętego w 1945 r. i przewiezionego do tarnowskiego ratusza księgozbioru Zborowskich jest trudna do ustalenia. W zachowanej dokumentacji, sporządzonej przez pracowników Biblioteki Muzeum Ziemi Tarnowskiej (BMZT) z tzw. „zwózki” zabezpieczonego mienia w $1945 \mathrm{roku}$, pojawiają się rozbieżne informacje na ten temat. W sprawozdaniu z 1 II 1945 r. wymieniono 111 tomów, które podzielono między szkoły i istniejące biblioteki, jeden dokument pergaminowy oraz zabezpieczoną bibliotekę w postaci 703 tomów wraz z archiwum rodzinnym $^{44}$.

Dokumentacja z zabezpieczenia wartościowych przedmiotów w Partyniu z dnia 7 II 1945 r. wykazywała między innymi: rysunek tuszem sepia z XVIII wieku, plany pałacu w Partyniu, sztychy, litografie, druki, rękopisy, nuty, zeszyty „Museionu” oraz różne inne wydawnictwa. W spisie znalazła się także informacja o jednej tece akt z XVIII wieku, roczniku „Wiadomości Literackich”, 703 tomach oprawionych, broszurowych oraz

${ }^{42}$ APwKOT, Archiwum rodziny Zborowskich z Partynia 33/227/3, Rachunki i korespondencja.

43 Świadczy o tym list z 4 X 1904 r. właściciela księgarni Alfreda Altenberga do J. Zborowskiego w sprawie zakupów dokonanych przez Stefana Zborowskiego. APwKOT, tamże.

${ }^{44}$ APwKOT, MOT 33/273/34, Sprawozdanie z prac wykonanych przy zabezpieczaniu zbiorów bibliotecznych na terenie pow. tarnowskiego i dębickiego od dn. I.II.1945 r. 
innych dokumentach ${ }^{45}$. Późniejszy dokument skierowany do Starostwa Powiatowego w Tarnowie z dnia 7 VI 1945 r. informował o przewiezieniu reszty ruchomości zabezpieczonych w Partyniu, w tym 1116 sztuk książek oraz innych przedmiotów z dworu w Pogwizdowie ${ }^{46}$. Z dokumentacji z przejęcia majątku w Pogwizdowie z dnia 14 II 1945 r. wiadomo o 1071 tomach - zarówno oprawnych, jak i broszurowych, dwóch szafach bibliotecznych, pięciu sztukach litografii i sztychów wodzów polskich oraz rysunku piórem W.E. Radzikowskiego ${ }^{47}$. Z dokumentacji BMZT wynikałoby, że łącznie księgozbiór (z Partynia i Pogwizdowa) Męcińskich i Zborowskich liczył ponad 2000 woluminów, jednakże oficjalnie podaje się liczbę przedstawioną w artykule Marii Żychowskiej - 921 tomów ${ }^{48}$.

Po II wojnie światowej w Tarnowie oprócz BMZT reaktywowana została także Biblioteka im. Juliusza Słowackiego, która utraciła ok. 45\% księgozbioru ${ }^{49}$. Ze względu na trudności organizacyjne zarząd tej placówki uznał jednak, że najlepszym wyjściem będzie przekazanie zachowanych resztek jej księgozbioru do BMZT. 2 VII 1945 r. obie instytucje połączyły swoje zbiory, a 1 I 1947 r. oficjalnie utworzono Miejską Bibliotekę Publiczną im. Juliusza Słowackiego ${ }^{50}$.

W 1949 r. przejęte kolekcje podworskie (w tym należące do Męcińskich i Zborowskich) uległy rozproszeniu. Dokonano podziału księgozbiorów w celu uzupełnienia strat wojennych innych bibliotek oraz zakładania książnic polskich na ziemiach zachodnich. Znaczna część książek, w tym stare druki, trafiły do Biblioteki Jagiellońskkiej, Biblioteki Uniwersytetu Wrocławskiego oraz składnicy książek w Katowicach. Do 2013 r. pozostałe w MBP książki i inne materiały biblioteczne z księgozbiorów podworskich funkcjonowały $\mathrm{w}$ następujący sposób: starodruki, książki XIX-wieczne, mapy, muzykalia i inne zbiory specjalne znajdowały się w Dziale Starych Druków i Książki XIX-wiecznej, a pozostałe książki wydane do 1945 r. (oraz nieliczne XIX-wieczne pozycje) były możliwe do wypożyczenia w: Wypożyczalni dla Dorosłych, Czytelni Naukowej, Dziale Książki Obcojęzycznej, Dziale dla Dzieci i Młodzieży oraz Centrum

\footnotetext{
${ }^{45}$ APwKOT, MOT 33/273/34, Spis zabezpieczonych przedmiotów sztuki w Partyniu $\mathrm{w}$ dniu 7 lutego $1945 \mathrm{r}$.

${ }^{46}$ APwKOT, MOT 33/273/34, Do Starostwa Powiatowego w Tarnowie.

${ }^{47}$ APwKOT, MOT 33/273/34, Spis książek i przedmiotów sztuki zabezpieczonych $\mathrm{z}$ dnia 14 lutego w Pogwizdowie (Odpis).

${ }^{48}$ Zob. M. Żychowska, Biblioteka Muzeum Ziemi Tarnowskiej, w: Muzeum Okręowe w Tarnowie, pod red. S. Potępy, [Tarnów] 1979, s. 37-38.

${ }^{49}$ Przed II wojną światową księgozbiór Biblioteki im. Juliusza Słowackiego wynosił 28 tys. woluminów - zob. Z dziejów Miejskiej Biblioteki Publicznej im. J. Słowackiego w Tarnowie 1908-1968, pod red. B. Jaśkiewicza, Tarnów [1970], s. 59.

${ }^{50}$ Zob. tamże, s. 90.
} 
Wiedzy o Tarnowie i Regionie. Obecnie planuje się wyłączenie z innych agend biblioteki książek XIX i XX w. i scalenie ich z pozostałymi zbiorami znajdującymi się w Dziale Starych Druków i Książki XIX-wiecznej w celu ochrony i - w miarę możliwości finansowych - digitalizacji.

\section{Charakterystyka książek z kolekcji Męcińskich i Zborowskich przechowywanej w MBP w Tarnowie}

Obecnie w zbiorach MBP w Tarnowie znajduję się 310 tytułów (w 274 woluminach) z XIX w. i pierwszej połowy XX wieku, jeden stary druk i zeszyt z rękopisami muzycznymi. Do końca 2013 r. zdołano opracować zaledwie jedną trzecią kolekcji. $Z$ dawnego inwentarza starych druków biblioteki ${ }^{51}$ wiemy jednak, że ze zbiorów rodziny z Partynia przejęto cztery pozycje ${ }^{52}$. Ponadto $\mathrm{w}$ trzech pierwszych inwentarzach MBP, powstałych po 1945 roku, można przy niektórych tytułach znaleźć adnotację o ich przynależności do kolekcji Męcińskich i Zborowskich ${ }^{53}$. W ten sposób odnotowano 160 pozycji, z czego 123 zostało umieszczonych na liście ubytków, a pozostałe można uznać za zaginione, ponieważ nie odnaleziono ich w żadnym z działów czy filii MBP. Wszystkie te tytuły, jak wynika z porównania z listą H.W. Zborowskiej, pochodzą z biblioteki w Pogwizdowie. Dodatkowo katalog Czytelni Naukowej wskazał siedem tytułów wydanych w XIX w. należących do Męcińskich, jednakże nie udało się ich zlokalizować w miejscu domniemanego przechowywania magazynie czytelni.

Unikatowym obiektem w kolekcji jest zeszyt ze szkicami muzycznymi oraz gotowymi utworami autorstwa P.M. Zborowskiego, ojca J.M. Zborowskiego. W zeszycie zachowały się: Galop, Landers, Polonaise, Valses, Mazur, Marsz Krakusów oraz 40 innych utworów, głównie walców, polek, oraz niedokończonych kompozycji zapisanych piórem lub ołówkiem. Ocalały również dwa utwory P.M. Zborowskiego ogłoszone dru-

${ }^{51}$ Inwentarz ten nie posiada strony tytułowej, ale dzięki poprawkom wprowadzanym w 1946 i 1947 r. w rubryce „Uwagi” można przypuszczać, że jest to spis pochodzący z BMZT, który według dokumentacji miał powstać jeszcze w 1945 roku, po zakończeniu zwózek mienia zabytkowego z dworów. Obecnie obowiązuje późniejszy inwentarz, powstały po podziale zbiorów pomiędzy MBP w Tarnowie i BJ, BUWr oraz składnicę książek w Katowicach. Nowy inwentarz obejmuje obecnie 525 pozycji.

52 Sa to: F. de La Rochefoucauld, Memoires de M. D. L. R. [...], Cologne 1669; S. Stawicki, Przeprawa Ladem i woda przez szrzeniawska rzekę do szczęśliwej wieczności portu [...], Kraków 1668; „Monitor Warszawski na Rok Pański 1765”, Warszawa 1765; Jan Kochanowski, Jana Kochanowskiego rymy wszytkie w jedno zebrane [...], Warszawa 1768. W MBP w Tarnowie znajduje się obecnie tylko ta ostatnia pozycja - pod sygn. SD-97.

${ }^{53}$ Zob. Inwentarze MBP $w$ Tarnowie za lata 1945-1950, t. 1-3. 
kiem: IV. Galops de Cracovie ${ }^{54}$ oraz Quatre Galops ${ }^{55}$. Przetrwała oryginalna tekturowa oprawa bulionu z błękitną mozaika.

Stan zachowania książek z XIX i pierwszej połowy XX wieku w przypadku przeważającej części egzemplarzy jest bardzo dobry. Kolekcja w większości (266 tytułów) składa się z książek, które pochodzą ze zbioru H.W. Zborowskiej. Ustalenie to przyjęto po porównaniu archiwalnej listy książek z Pogwizdowa z pozycjami zachowanymi w MBP w Tarnowie.

Ponad połowa ze znajdujących się tam książek to literatura piękna, proza i poezja. Wśród polskiej i obcej literatury znalazły się dzieła większości poczytnych pisarzy i poetów XIX i początku XX wieku. Dość często pojawiają się tomy publikowane $\mathrm{w}$ ramach edycji dzieł zbiorowych danego autora lub wydawnictw seryjnych, między innymi: Biblioteki Najciekawszych Powieści i Romansów, Biblioteki Uniwersalnej Arcydzieł Polskich i Obcych, Biblioteki Dzieł Wyborowych, Biblioteki Pisarzy Polskich, Wydawnictwa imienia Kasyldy Kulikowskiej, Collection of British Authors, Dürr's Collection of Standard American Authors, Collection Manz.

Druga pod względem liczebności jest grupa tytułów z zakresu historii (najczęściej pamiętniki lub wspomnienia znanych osobistości). Dość licznie występują tu tytuły z serii Dzieje Porozbiorowe Narodu Polskiego Gebethnera i Wolffa oraz Biblioteki Historycznej Księgarni Polskiej we Lwowie. Pozostałe grupy stanowia publikacje z zakresu polityki, historii sztuki, psychologii.

Blisko jedna trzecia zachowanych książek ukazała się w oficynach zagranicznych, choć były to często wydawnictwa w języku polskim, np. w oficynie Brockhausa w Lipsku. Edycje polskich nakładców pochodziły głównie z zaboru austriackiego, na terenie którego mieszkali właściciele księgozbioru. Józef G. Męciński często podróżował do Lwowa i Krakowa ze względu na obowiązki społeczne i polityczne. Pozycje z warszawskiej oficyny Gebethnera i Wolffa oraz poznańskiej Księgarni Jana K. Żupańskiego prawdopodobnie nabywał za pośrednictwem krakowskich czy lwowskich księgarni sortymentowych. Helena Męcińska z Dobrzyńskich miała w swym zbiorze książki pochodzące głównie z Lipska, $\mathrm{z}$ oficyny Brockhausa (w tym również pozycje odziedziczone po swojej matce, Wiktorii Dobrzyńskiej). Jan Zborowski z kolei, ze względu na pełnienie funkcji szambelana dworu Jego Cesarskiej Mości Franciszka Józefa, był częstym gościem w Wiedniu i Lipsku, skąd pochodziły zachowane egzemplarze książek będące własnością Zborowskiego. Natomiast

${ }^{54}$ Zob. P. Zborowski, IV. Galops de Cracovie, chez A. Brzezina, Warszawa [b. r.].

${ }^{55}$ Zob. tenże, Quatre Galops, chez P. Piller'a Leopol, Lith [b. r.]. 
do H.W. Zborowskiej należały tytuły zakupione w innych europejskich ośrodkach wydawniczych, jak i w Ameryce.

Zachowane egzemplarze omawianej kolekcji posiadają ważne znaki proweniencyjne. Udokumentowano proweniencje 184 spośród 310 tytułów. Najliczniej w kolekcji reprezentowane są książki należące do J.G. Męcińskiego - 93 woluminy oraz jeden starodruk. Męciński oznaczał swoje książki pierwotnie podpisem odręcznym na stronie tytułowej przy użyciu czarnego atramentu, natomiast z czasem zaczął wykorzystywać faksymile podpisu, przy użyciu granatowego tuszu. Wśród książek Józefa znalazły się dwie z Wypożyczalni Książek W. Jaworskiego w Krakowie ${ }^{56}$. Czy zostały odkupione, czy też ich nie zwrócono, nie wiemy, ponieważ brak informacji

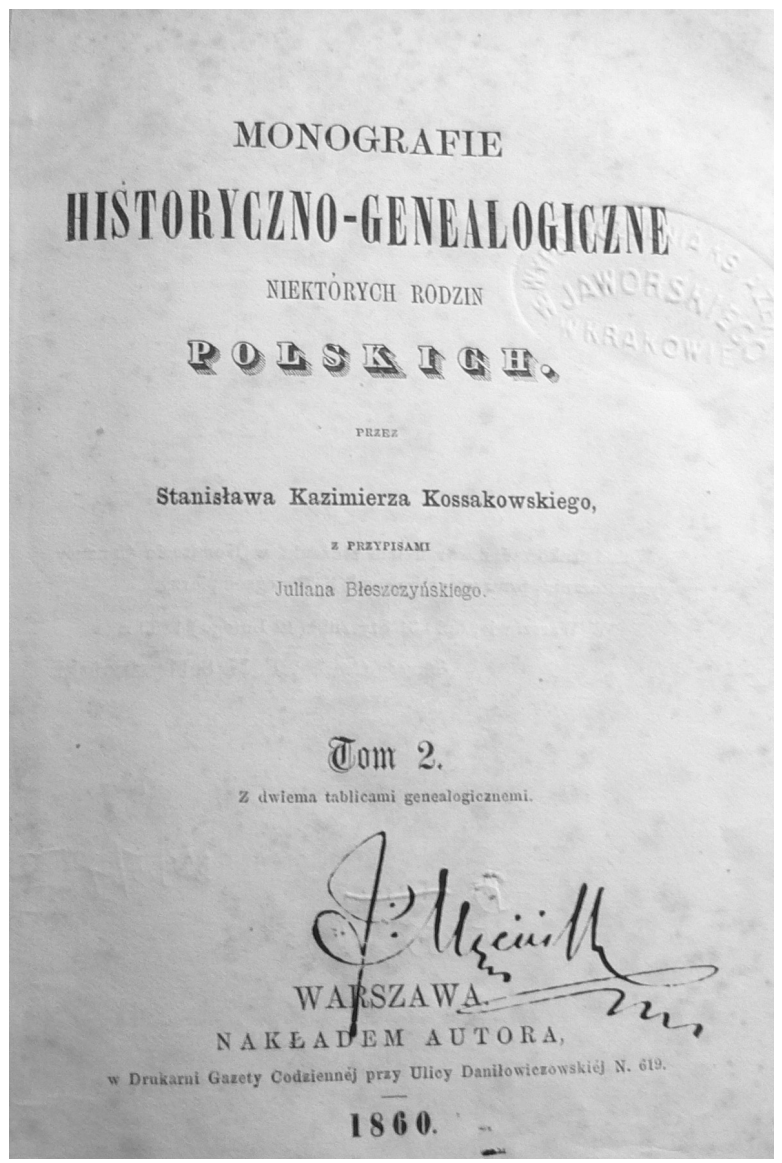
na ten temat. W przypadku trzech książek zachowały się inicjały „J.M.” wyciśnięte na dole grzbietu tomu oprawionego $\mathrm{w}$ czarną skórę.

Wśród 30 książek z podpisami H.M. Męcińskiej znajdziemy zarówno książki z jej panieńskim podpisem, jak i $\mathrm{z}$ nazwiskiem męża. Jej autograf często widniał na tych samych książkach, które zostały już oznaczone przez J.G. Męcińskiego (23 woluminy) oraz które należały wcześniej do jej matki, W. Dobrzyńskiej

Fot. 3. Odręczny podpis J. Męcińskiego, sygn. B-5855

56 Były to: S. K. Kossakowski, Monografie historyczno-genealogiczne niektórych rodzin polskich, t. 1, Warszawa 1859 (sygn. B-5854) i t. 2, Warszawa 1860 (sygn. B-5855). 
(4 książki). Helena swój podpis zawsze składała na stronie tytułowej lub ją poprzedzającej, w dolnym prawym rogu.

H.W. Zborowska podpisała 55 pozycji - wśród nich książki będące przedtem w posiadaniu innych członków rodziny, o czym świadczą wcześniejsze znaki proweniencyjne. Hrabina używała różnych wersji swojego podpisu. Pierwsze pochodzą okresu panieńskiego, kiedy to dla odróżnienia woluminów swoich od matki dodawała datę i miejsce włączenia książki do własnych zbiorów. $Z$ czasem podpisywała się imieniem i nazwiskiem oraz dodawała aktualne miejsce zamieszkania: Zgłobice, Partyń, Pogwizdów. Pisarka zawsze oznaczała tomy na górze strony przedtytułowej lub wyklejce za pomocą pióra, ołówka bądź też kolorowej kredki. Najwięcej - bo aż 21 - zachowanych egzemplarzy posiada dopisek Partyń, po 17 przypada dla Zgłobic i Pogwizdowa, chodź niekiedy wymieniono np. Zgłobice, a następnie Partyń.

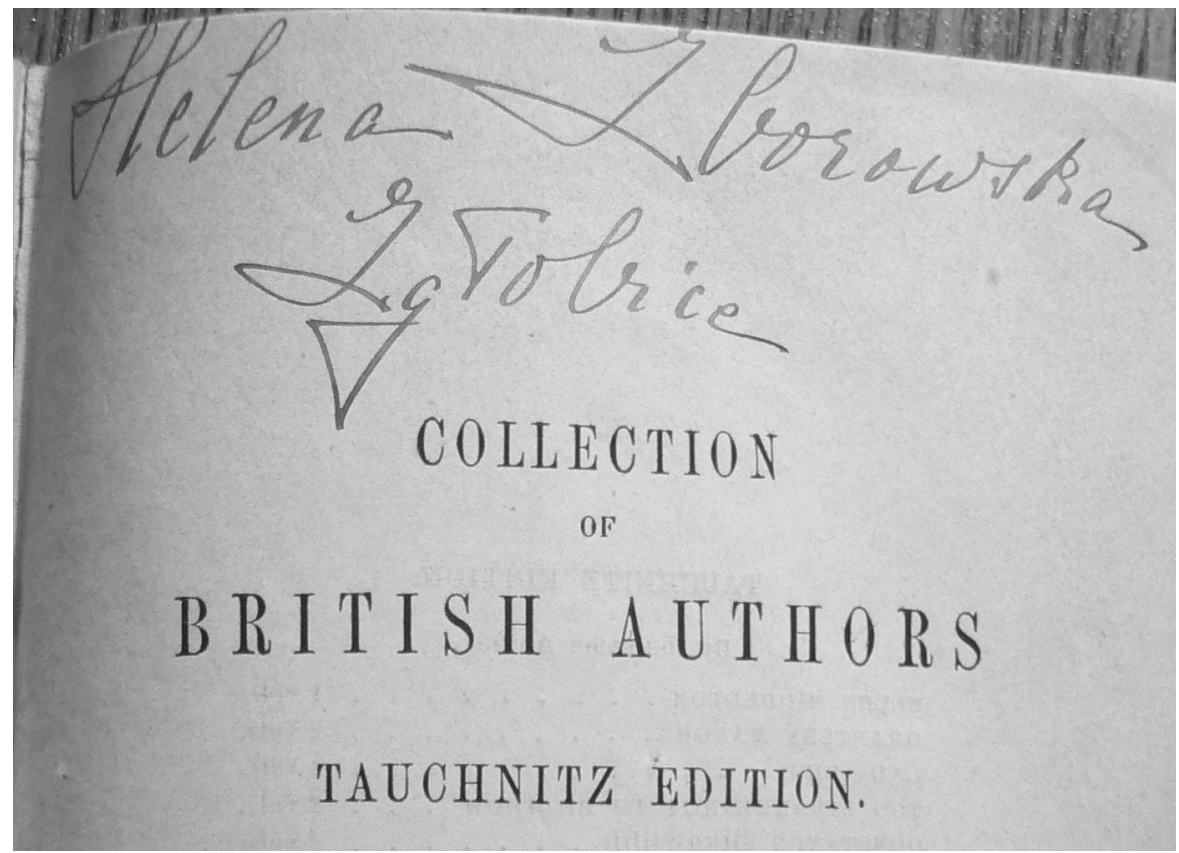

Fot. 4. Odręczny podpis H. Zborowskiej, sygn. Z-2318

W kolekcji książek należących do H. Zborowskiej pojawiły się także dwie pozycje należące do innych kobiet: R. Męcińskiej (siostry H. Zborowskiej) oraz I. Zborowskiej (córki). Mąż hrabiny, J. Zborowski, jako jedyny z rodziny nie podpisywał swoich książek, a znakował je przy uży- 
ciu pieczęci ze swoimi inicjałami. Zachowały się 22 woluminy w języku niemieckim i jeden $\mathrm{w}$ języku polskim $\mathrm{z}$ taką proweniencją. Pieczęć odbijano zawsze na wyklejce w czterech narożnikach oraz pośrodku.

Kolejny właściciel kolekcji, syn Jana i Heleny Zborowskiej - Aleksander, podpi-

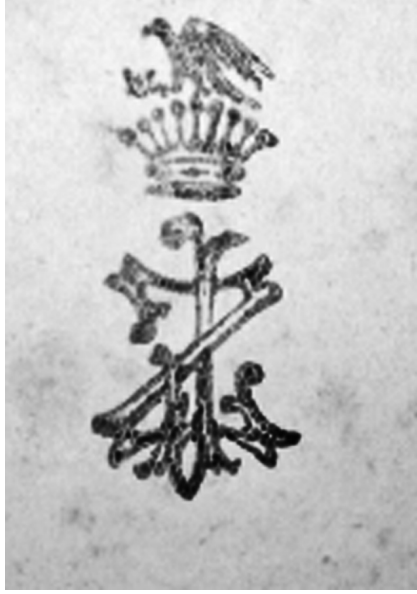

Fot. 5. Pieczęć J. Zborowskiego, sygn. C-53548 sywał swoje książki dość nieczytelnie. Jego podpis $\mathrm{w}$ dwóch wariantach występuje na siedmiu tomach, które odziedziczył po rodzicach. A. Zborowski składał go, podobnie jak jego matka, na górze strony tytułowej lub ją poprzedzającej i uzupełniał opis o miejsce zamieszkania - „Partyń”, a w dwóch przypadkach ponadto także o datę. Na jednym z woluminów należących do Aleksandra pojawił się podpis Eli Srogowskiej ${ }^{57}$.

W całym rodowym księgozbiorze odnajdujemy siedem dedykacji, $w$ tym trzy $\mathrm{w}$ języku angielskim. W tomach z kolekcji Męcińskich i Zborowskich można ponadto natrafić na zapiski czytelnicze poczynione przez właścicieli książek podczas lektury. Najczęściej są to poprawki i uwagi co do treści lektury, tworzone w formie przypisów, np. przez J. Męcińskiego w Szkicach historycznych Ludwika Kubali ${ }^{58}$ lub na luźnych kartkach włożonych do woluminów.

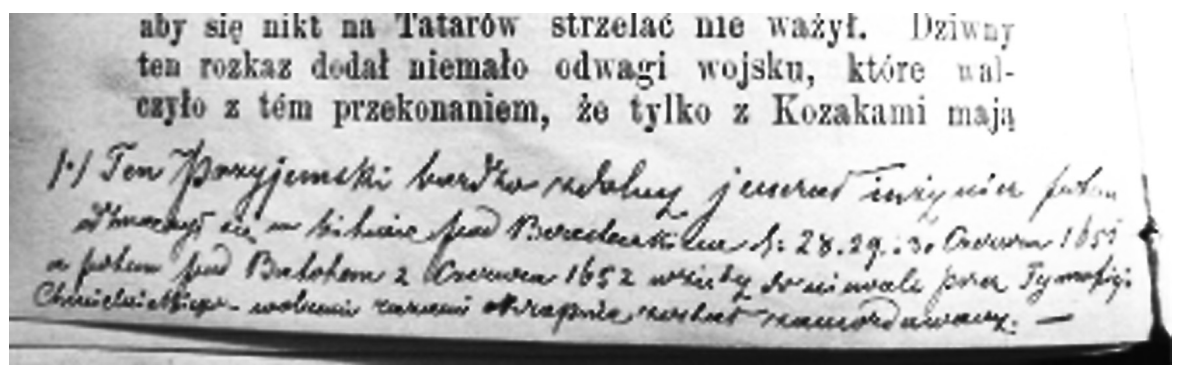

Fot. 6. Przykład notatki pióra J. Męcińskiego, sygn. C-25227

Wśród 307 jednostek wydawniczych w 271 woluminach aż dla 146 woluminów wykonano oprawy na zamówienie. Niestety, nie udało się ustalić nazwiska introligatora, z którego usług korzystano. Dodatkowo należało-

${ }^{57}$ Prawdopodobnie była to siostrzenica ojca Aleksandra - J. Zborowskiego, jednak w publikacjach genealogicznych nie udało się dotrzeć do takich informacji.

${ }^{58}$ Zob. L. Kubala, Szkice historyczne, Seria 1, Lwów 1881, sygn. C-25227. 
by dodać do tej liczby egzemplarze z wydawnictwa seryjnego Bernharda Tauchnitza. Tomy te pierwotnie, jak można przypuszczać na podstawie innych zachowanych egzemplarzy z serii, posiadały czerwoną oprawę z tekturową mozaika, a obecnie zostały na nowo oprawione przez MBP.

Oprawy wykonane na zamówienie właścicieli występują w sześciu wariantach kolorystycznych. Napisy na grzbietach książek, niezależnie od typu oprawy, były złocone i uwzględniały nazwisko autora, tytuł oraz numer tomu, najczęściej wytłoczone czcionką o secesyjnym kroju. Niestety, nie wszystkie z zapisków introligatorskich zachowanych na tomach można było rozszyfrować. Prawdopodobnie właściciele Partynia ze względów ekonomicznych oprawiali swoje książki w Tarnowie, Krakowie lub we Lwowie. 101 książek posiada oryginalne oprawy wydawnicze.

Ze względu na wartość, jaką posiada zachowany fragment księgozbioru Męcińskich i Zborowskich, stanowiący dziedzictwo kulturowe, które szczęśliwie dotrwało do naszych czasów, bardzo istotne jest zapewnienie pełnego opisu bibliograficznego kolekcji poprzez jej skatalogowanie wraz z podaniem dokładnych informacji zarówno o proweniencji, jak i o zabezpieczeniu przed czynnikami fizycznymi i biologicznymi wpływającymi negatywnie na stan zachowania woluminów.

\section{Streszczenie}

\section{Kolekcja ksią̇ek Męcińskich i Zborowskich w zbiorach Miejskiej Biblioteki Publicznej im. Juliusza Słowackiego w Tarnowie}

Ziemię tarnowską zamieszkiwały do 1945 r. liczne rody ziemiańskie. Wśród nich wyróżniali się przedstawiciele rodzin Męcińskich i Zborowskich z Partynia: Józefa Gabriela Męcińskiego (1837-1921) powstańca styczniowego, posła na sejm i działacza społeczno-politycznego oraz jego córkę Helenę Wiktorię Zborowską (1876-1943) znaną w pierwszej połowie XX w. powieściopisarkę i nowelistkę, która debiutowała pod pseudonimem Blanka Halicka powieścią Kto zwycięży? w $1901 \mathrm{r}$.

Właściciele Partynia zgromadzili w swoim dworze ciekawy księgozbiór, którego fragment przechowuje od 1945 r. i reformy rolnej Miejska Biblioteka Publiczna im. Juliusza Słowackiego w Tarnowie. W kolekcji tej dominuję literatura piękna, wraz z opracowaniami z zakresu historii literatury oraz historia reprezentowana głównie przez pamiętniki znanych osobistości. Ponadto w kolekcji występują licznie książki wydawane w seriach lub wydawnictwach wielotomowych. Językiem dominującym w zachowanym fragmencie jest $\mathrm{j}$. polski. 
Książki posiadają różnego typu oprawy wykonane na zamówienie oraz ciekawe oprawy wydawnicze - zwłaszcza tytuły w języku niemieckim. W kolekcji przeważa jeden typ znaków proweniencyjnych - podpis odręczny, który preferowała większość członków rodzin Męcińskich i Zborowskich. W zachowanym fragmencie księgozbioru z Partynia znajdują się unikatowe wydania zarówno w języku polskim, jak i obcych, dostępne w nielicznych ośrodkach w Polsce. Z tego powodu kolekcja ma znaczenie nie tylko dla historii regionu tarnowskiego, ale jest cennym dziedzictwem narodowym.

\section{Summary}

\section{Books from the Męciński and Zborowski Family Collections in the Holdings of the J. Słowacki Municipal Public Library in Tarnów}

Until 1945, the Tarnów region was inhabited by numerous families belonging to the gentry. Among the members of these clans one finds two distinguished representatives of the Męcińskis and the Zborowskis from Partyń: Józef Gabriel Męciński (1837-1921) - participant of the patriotic January Uprising, social and political activist, and his daughter Helena Wiktoria Zborowska (1876-1943) a famous novelist and author of short stories, who published her first book under the pseudonym Blanka Halicka in 1901.

In their residence, the possessors of the Partyn manor put together an interesting book collection, a fragment of which is preserved at the J. Słowacki Municipal Public Library in Tarnów. The collection was dominated by literary fiction accompanied by historical works, and memoirs of famous personalities. Apart from that the collection encompassed numerous book series and multivolume editions. The majority of the extant books are in Polish. Of note are various bindings, made on order of the owners of the collection, and interesting bindings furnished already by the publishers, in particular with respect to German books. Among provenance marks left on the books by their owners, one is most typical - handwritten signature - obviously preferred by the majority of the family. The extant fragment of the collection encompasses a number of unique specimens of Polish and foreign editions, available only in few other libraries in Poland. Thanks to this fact, the Męciński - Zborowski collection should be treated not only as regional but also national heritage. 